\title{
Japanese language, gender, and ideology: Cultural models and real people. Edited by Shigeko Okamoto and Janet S. Shibamoto Smith. Oxford: Oxford University Press, 2005. pp. 316.
}

\author{
Reviewed by Katsue Akiba Reynolds
}

Japanese language, gender, and ideology: Cultural models and real people is the second collection of studies concerning 'Japanese language and gender' published in English. The first collection by Sachiko Ide and Naomi H. McGloin was published in 1990, when there were very few studies on the topic available in English. (The abbreviated term, 'Japanese-language-and-gender studies' refers to studies in English below unless otherwise specified.) It can be said that this area of Japanese gender studies began to evolve during the latter half of the 1980 s and it became increasingly visible in the 1990s. It is not only in quantity that Japanese-language-and-gender studies have grown, but also in the extent to which researchers are involved in the theoretical debates concerning gender and language. Japanese language, gender and ideology is an excellent example of the development of Japanese gender research.

Japanese language, gender and ideology is provocative in two respects: (i) it is an ambitious challenge to previous studies of Japanese culture and language, which are seen in this project as essentializing notions of language, gender and culture; and (ii) it orients itself towards recent language and gender research influenced by poststructuralist thought in the West, thus aligning itself with

\footnotetext{
$\overline{\text { Affiliation }}$

Katsue Akiba Reynolds, Department of East Asian Languages and Literatures, University of Hawai'i at Manoa, Moore 382, 1890 East-West Road, Honolulu, HI 96822

email: katsue@hawaii.edu
} 
'universalism', a mode of global theory construction which third-world feminists would challenge from a postcolonialist perspective. Japanese language, gender and ideology, therefore, offers a great opportunity to consider the viability of poststructuralism, the internationalization of gender and language studies, and the role of Japanese in the process. It is of course neither my role here nor is it within my ability to address these larger questions. What I can do is bring attention to certain issues while discussing the high points of selected chapters in relation to them.

The volume begins with the introduction and is followed by 15 chapters divided into three parts: Part I 'Historical and theoretical foundations', Part II 'Linguistic ideologies and cultural models', and Part III 'Real language and real people. The introduction, together with the section headings, provides a helpful guide for readers to what this book is about.

The introduction first disparages existing models of Japanese culture and makes a wholesale attack on them for promoting stereotypes of the Japanese, thus generating the polarity between 'previous studies' of Japanese culture ('Japan-is-unique' relativism) and the cultural view in the background of Japanese language, gender and ideology ('universalism'). This familiar pattern of opposition has lurked in the thinking of many American scholars in the field of Japan Studies. It flared up during the US-Japan trade war at the end of the 1980s. ${ }^{1}$ Japanese language, gender and ideology, making a definitive statement that women's and men's language are 'cultural constructs informed by the hegemonic ideology' (4), accuses 'previous studies' of complying with the ideology by essentializing categories of women's and men's language. This is a strong position of constructionism reflecting the radical view of gender and language as presented by Judith Butler (1990), who has argued for collapsing the analytic distinction between sex and gender. Her work was interpreted as saying, 'both sex and gender ... are constructed categories, and neither exists independently of, or prior to, language' (Norton 1997:24).

The introduction has a strong contentious tone, which in fact characterizes much of poststructuralist writing. Thinkers concerned with the serious impasse caused by combativeness, however, are now attempting to overcome conceptual dichotomies, such as, 'essentialism vs. social constructionism' and 'normative vs. real'. For example, Nancy J. Finley and Rose L. Norman (1997) propose the concept of 'social parallax', allowing for 'the possibility of a third option already embedded in the dichotomy' (5). Recognizing that the problem is particularly obvious in the debate over essentialism, they quote Diana Fuss (1989), 'essentialism is neither good nor bad, progressive nor reactionary, beneficial nor dangerous. The question is ... what motivates its deployment?' (7). Beatrice Hanssen's (2000) concept of 'between-ness' and Claudia Moscovici's (2002) 'double dialectics' are other examples. Judith Butler herself has shifted 
from extreme constructionism ('linguisticism' in her term) and now distinguishes sex (material) and gender (conceptual) (e.g., Butler 2001). Norton (1997), identifying himself as 'gay and transgendered ... married to a woman and has three children', argues persuasively that the claim that 'sex is a socially constructed phenomenon is false' (24). He continues that even though there is no pure, elemental maleness or femaleness, most human beings exist 'along generally 'male' or 'female' lines' (25). He contends that, if feminism is to be justified, 'it must be on the basis of contingent, historically-located notions of right that are not purely abstract, but that are shaped by, and determined in relation to, human lives as they are lived' (29). So, he suggests that it is time to re-correct the excesses of poststructuralism.

Chapter 1 'Cultural ideologies in Japanese language and gender studies - A theoretical review' by Masahiko Yukawa and Masami Saito critically traces the development of Japanese language and gender studies in Japan. The chapter, placing great importance on the role that language and gender studies can have in subversive identity construction and in movements for social change, gives special credit to Akiko Jugaku (1924-2005), a scholar of Japanese language studies, because her work 'oriented later researchers more directly to the important connection between language and cultural ideologies' (26). ${ }^{2}$ Nihonngo to onna (The Japanese language and women), Jugaku's most famous book, published in 1979, is comparable, as the authors state in Chapter 1, to Robin Lakoff's Language and woman's place in that it was intended to enlighten the Japanese about sex discrimination in Japanese language and culture in a style accessible to the public. In contrast, the authors criticize sociolinguistic studies of 'women's language', in particular, Sachiko Ide. They charge that she discusses 'in abstract terms normative usages of Japanese women's speech assumed to be used by middle-class women in the Tokyo metropolitan area,' and that her theory fails to consider 'the hierarchical gender structure and its mechanisms of control, thereby reinforcing hegemonic gender ideologies' (28).

Chapter 3 'Gender, language, and modernity: Toward an effective history of "Japanese women's language"' by Miyako Inoue is a brilliant application of the Foucauldian method of genealogy to historical texts of pre-modern and modern Japan. The Meiji Restoration, the radical change in the political system from feudalism (pre-modern) to constitutional monarchy (modern) in 1868, necessarily affected all the aspects of Japanese life. Focusing on 'the linguistic modernization movements' variously pursued for different goals by the government agencies, the literary community, and other institutions and actors from the late nineteenth century to the early twentieth century, Inoue is able to say that 'history here involved the opening of new cultural space where women became objectified through their language use' (59). Over and against views which root Japanese women's language in long-standing cultural

\section{equinoxonline}


practices, Inoue argues that the process by which a particular speech form is selected or negotiated out of multiple competing voices and interpretations at any given moment to become an institutionally discrete index of femaleness is an inescapably political process (71). Chapter 4 " "Japanese female speech" and Language policy in the World War II era' by Rumi Washi provides evidence that the Ministry of Education played a crucial role in constructing and propagating gendered speech for women. The fact that these chapters are valuable contributions to the constructionist framework of the book raises a question as to the meaning of 'real', a recurring term in the book in phrases such as, 'real language practices of real people,' and 'real linguistic data.' 'Real' occurs 24 times in the introduction. This emphasis on 'real' would be puzzling to sociolinguists who have worked their fullest to gather 'natural data' in spite of the so-called observer's paradox. If 'real' means tape-recorded natural conversation, these chapters would belie the advocated methodology. Without an explanation for the meaning of 'real', it is confusing. Unlike Labov, who attempts to understand the past from the present, i.e., tape-recorded spoken data, today's historical sociolinguists consider it imperative to open 'windows on texts and discourses of the past' (Skaffari et al. 2005). If written material in these chapters is considered 'real', then, what is 'real'?

Chapter 5 'Shifting speakers: negotiating reference in relation to sexuality and gender' by Wim Lunsing and Claire Maree, Westerners residing in Japan, is also of great significance. They interacted with gays and lesbians and observed many instances of problems posed by heterosexism in Japanese. Gays and lesbians feel 'that they do not fit into this binary structure' of women's and men's language (105). This chapter is timely because it reflects changing social attitudes in Japan. ${ }^{3}$

Part II consists of four chapters which exemplify how the cultural model of women's speech is constructed through various forms of media - fictions, magazines, dictionaries, etc. Momoko Nakamura (Chapter 7: "'Let's dress a little girlishly!" or "Conquer short pants!" Constructing gendered communities in fashion magazines for young people') reiterates the importance of 'the dichotomous female/male distinction while emphasizing the diversity of female identities, and points out the danger of dispensing with the category of women, which is necessary to unite feminist movements (132). At a conference of the Women's Studies Association of Japan, held on 9-10 June 2007, a major event was a symposium on the issue of the 'binary' approach to gender in relation to the current socio-political climate of gender bashing. It is now one of the major issues among Japanese feminist researchers. Nakamura is a feminist scholar who has paid close attention to political movements in Japan while she has productively worked to integrate western language and gender theories into her research. 
The inclusion of Chapter 9 'Women and words: The status of sexist language in Japan as seen through contemporary dictionary definitions and media discourse' by Orie Endo in Japanese language, gender and ideology, a book espousing third-wave feminism, is somewhat surprising. 'Sexist language' is a typical second-wave issue widely discussed not only in the United States but also in Japan since the 1970s. For example, in 1977, Kimi Komashaku (1925-2007), a literary scholar prominent in the second-wave feminist movement in Japan noted that Japanese abounds with words for the purpose of evaluating women from men's point of view while the reverse is seldom found. She contended, 'This means that women have never been subjects in this society' (81). In the 1980s and 1990s there were many booklets and pamphlets listing sexist words produced at first by grass roots women's groups and later by governmentsupported groups. Endo's criticism of 'derogatory terms', which she started in the early eighties, is an important contribution to the movement towards 'linguistic equality'. Underlying such studies and movements is the insight, as Endo states, that 'the existence of sexist language supports and reproduces sexist attitudes' (166), and the fact that a topic has been raised earlier does not mean the social problem it represents has been fully addressed. The rift between 'previous studies' and 'new studies' may not in fact be as fundamental as is claimed.

Chapters in Part III all include tape-recorded data except one. They intend to demonstrate social, situational, and personal variations within women or men: three farm women (Ch. 10), employees of lesbian bars (Ch. 11), business women in Hawaii (Ch. 12), PTA women in Tokyo (Ch. 13), high school pupils in classes (Ch. 14), and a group of men from different regions (15). Each study has interesting points but the fact that speech patterns vary among women (or men) does not sufficiently support the claim against the use of 'women's language' as an analytical tool. Yumiko Ohara's study (Ch. 12: Prosody and gender in workplace interaction) is a refinement of her earlier study in which she demonstrated the gender differences in voice pitch induced by the cultural expectation in speaking Japanese. Based on new samples collected in workplace interactions, Ohara is now able to say that 'high-pitched voice is a device that can be used by both women and men to create a certain effect, namely, emphasis' (p. 236) while pointing out at the same time the data, nevertheless supports 'the claim in previous research that women in Japan face cultural constraints that lead them to raise the pitch of their voice in order to project a feminine image' (237).

This rough outline of Japanese language, gender and ideology allows us to turn to the question of the internationalization of gender and language studies. In the preface to Japanese language, gender and ideology, Mary Bucholtz acknowledges 'the Japanese language has played a foundational role in the

\section{equinoxonline}


development of language and gender as an area of linguistic research' (vii). It has certainly played a role, if not a foundational one. Japanese has attracted some researchers from the beginning of the feminist study of language and gender while little attention has been given to other non-western languages. When Cheris Kramarae and Beth Stafford (1984) expressed the intention of making language and gender research international, Women and language privileged Japanese by appropriating separate space for a 'Japanese bibliography'. There seems to be an expectation that Japanese-language-and-gender studies can be a stepping-stone on the road to internationalization. Can it be? A critical examination of Japanese language, gender and ideology gives some clues to think how this could be.

i. The idea of internationalizing gender and language research has been met with resistance from third-world women (see Women and language, 1988, Winter). Recently, Angeli Diaz (2003) has recapitulated the argument against internationalization, reminding readers that third-wave feminisms in the West can often be imperialist. For this reason, she rejects what she sees as the universalism of the third-wave feminisms in the US. Other Asian postcolonial feminists go even further by advocating a 'nationalist feminism' (Anguilar 1998). Although Japan is identified as a first world, or developed, country in economic terms, it is certainly not in terms of gender equality. Japan was ranked $41^{\text {st }}$, lowest among the developed countries, by a UN survey (2000). Where does Japanese gender research stand between the first and the third world? This question, although it is not explicitly on the agenda of Japanese language, gender and ideology, should never be taken as irrelevant. In the time of globalism and postcolonialism, any crosscultural endeavor of knowledge construction is inexplicably tied to the general issue of multiculturalism and nationalism.

ii. How does Japanese language, gender and ideology, heavily influenced as it is by Western feminist thought, meaningfully and effectively relate itself to the socio-political condition in Japan, and particularly, to rising nationalism and gender bashing? Dismissing the category of 'women' may weaken, as Nakamura suggests in Chapter 7, the basis of the feminist movement and its ability to resist top-down measures designed to undermine gains already made. Nationalists and conservatives exploit the semantic multiplicity of 'gender' as a discursive weapon to divide feminisms. They claim that the phrase 'gender-free,' which has been widely used in different educational contexts to eliminate sex-discriminatory practices, is not properly defined and causes confusion. The national government office issued memos defining the

\section{equinoxonline}


meaning of gender, the Metropolitan government actually banned the word in official documents, and the scheduled public lecture on human rights by Chizuko Ueno (Tokyo University professor), the most famous Marxist-feminist in Japan, was cancelled by the officials of the Tokyo government for fear that she might use the words 'gender' and 'gender-free'. On 25 March 2006, several hundred feminist researchers and activists finally gathered to clarify the concept of gender and came up with a resolution that women must work together in spite of theoretical differences. ${ }^{4}$ Japanese-language-and-gender studies can be constructive only when they are linked to feminist issues in Japan and to the daily struggles of Japanese people. The internationalization of language and gender studies might become acceptable to feminists outside the West, if it is proven to be sufficiently attentive to differences among cultures.

iii. Another important question concerns the chasm between Japaneselanguage-and-gender studies in English and those in Japanese. Researchers of the former are Japanese-speaking but their audience is mostly made up of non-Japanese-speakers. The outcome is therefore significantly different from that of Japanese-language-and-gender studies written in Japanese, and tends not to be fully connected with studies in Japanese as seen for instance from the references appended to the chapters in Japanese language, gender and ideology. Van Dijk (1998), editor of Discourse studies, an international journal, suggests that internationalization means, among other things, that writers should use scholarly literature, as well as discourse data, from various languages and countries (436). Indeed, there is now an enormous quantity of Japanese-language-and-gender studies published in the Japanese language. In addition to books such as Nakamura (2001), Endo (2001), Sasaki (2006), and Ide (2006), there are numerous papers and articles published in widely circulated journals of language studies, such as Nihongo-gaku (Japanese language studies) and Gekkan gengo (Monthly language), studies reported in university annals, essays published in various magazines and newspapers. In the majority of the studies there is very little reference to any model of gender and language studies produced in the West. This means a barrier exists from the Japanese side as well.

If Japanese-language-and-gender studies indeed play a foundational role in the process of internationalization of feminist theory, it must contextualize itself between first world and third world, and between theory and practice, seeing beyond the U.S.-Japan playing field. The internationalization of academic schol- 
arship is overwhelmingly difficult (see van Dijk 1997, 1998) and there seems to be no resolution in sight. We may gain valuable insight from the succinct statement by Gayatri Spivak (2007): 'Translation is necessary but impossible.'

\section{Notes}

1 Newsweek (9 October 1989), a special issue, 'Japan Invades Hollywood, provides an example.

2 Jugaku had established herself as a scholar of Medieval Japanese before she began to write on women's life and language in the late 1970s.

3 In 2003 Otsuji Kanako ran for political office in Osaka and won the election, and she 'came out' by writing an autobiographical book. She is the first political office holder to be openly lesbian.

4 Several books were published on this problem in 2006. Wakakuwa Midori et al. (2006) summarizes the discussions at the March 25th meeting.

\section{References}

Aguilar, Delia D. 1998. Towards a nationalist feminism. Giraffe/PALH.

Butler, Judith. 1990. Gender trouble: Feminism and subversion of identity. New York: Routledge.

Butler, Judith. 2001. How can I deny that these hands and this body are mine? In Tom Cohen, Barbara Cohen, Hills Miller and Andrzei Warminski (eds). Material events: Paul de Man and the afterlife of theory. Minneapolis: University of Minnesota Press, 254-276.

Diaz, Angeli R. 2003. Postcolonial theory and the third wave agenda. Women and language XXVI(1):10-17.

Endo, Orie. 2001. Onna to Kotoba (Women and language). Tokyo: Akashi Shoten.

Finley, Nancy J. and Rose L. Norman. 1997. The concept of social parallax. Women and language XX(1):5-8.

Fuss, Diana. 1989. Essentially speaking: Feminism, nature, and difference. New York: Routledge.

Hanssen, Beatrice. 2000. Whatever happened to feminist theory? In Elisabeth Bronfen and Misha Kavka (eds). Feminist consequences: Theory for the new century. New York: Columbia University Press, pp. 58-100.

Ide, Sachiko and Naomi H. McGloin. 1990. Aspects of Japanese women's language. Tokyo: Kuroshio.

Ide, Sachiko. 2006. Wakimae no goyooron. (Pragmatics of discernment.) Tokyo:

Taishuukan. 
Jugaku, Akiko. 1979. Nihongo to onna (The Japanese language and women). Tokyo: Iwanami Shoten.

Komashaku, Kimi. 1977. "Tsuma" to "kindai" ("Wives" and "modern"), Dentoo to gendai (Tradition and present). 49:81-7.

Kramarae, Cheris and Beth Stafford. 1984. World word-shaking: Women everywhere (or at least a start). Women and language VIII(1/2):3-5.

Lakoff, Robin. 1975. Language and woman's place. New York: Harper \& Row.

Moscovici, Claudia (ed.). 2002. Double dialectics: Between universalism and relativism in enlightenment and postmodern thought. Oxford: Rowman and Littlefield.

Nakamura, Momoko. 2001. Kotoba to Jendaa (Language and gender). Tokyo: Keiso Shobo

Norton, Jody. 1997. Bodies that don't matter: The discursive effacement of sexual difference. Women and language XX(1):24-30.

Sasaki, Mizue (ed.). 2006. Nihongo to Jendaa (Japanese language and gender). Tokyo: Hitsuji Shobo.

Skaffari, Jane, Matti Peikola, Ruth Carroll, Risto Hiltunen and Brita Wårvik (eds). 2005. Opening windows on texts and discourses of the past. Amsterdam, Philadelphia: J. Benjamins Pub.

Spivak, Gayatri Chakravorty. 2007. International symposium at the University of Hawaii, 22-23 January 2007: Translation: Theory, practice, trope.

Van Dijk, Teun A. 1997. Editorial: The imperialism of English. Discourse \& society 8(3):291-292.

Van Dijik, Teun A. 1998. Editorial: Discourse studies. Discourse \& society 9(4):435-436.

Wakakuwa Midori, Kato Shuichi, Minagawa Masumi and Akaishi Chieko (eds). 2006. 'Jendaa no Kiki o Koeru! - Tettei Tooron! Bakku Rasshu. (Overcoming the crisis of 'gender' - Thorough discussion: Backlash.) Tokyo: Seikyuusha. 